\title{
NON-PROFIT ORGANIZATIONS IN HUNGARIAN RURAL DEVELOPMENT - A LEADER+ EXAMPLE IN THE SOUTHERN TRANSDANUBIAN REGION ${ }^{1}$
}

\author{
Eszter Varga ${ }^{2}$
}

Received 22 September 2008; Accepted 9 March 2008

\begin{abstract}
After reviewing some of the most important features of Hungarian rural development, the paper attempts to explore participation and roles of non-profit organisations in this field, through the lenses of the LEADER+ Programme. As a study area, one of the seven development regions of Hungary, the Southern Transdanubian Region was selected for the analysis. On the basis of the results and the reviewed literature, the author gets to the conclusion that rural non-profit organisations have an important role to play in animating and mobilizing rural population
\end{abstract}

Key words: rural development, non-profit organisations, LEADER Programme, Southern Transdanubian Region

Kivonat: A magyar vidékfejlesztés néhány legfontosabb jellemzőjének áttekintését követően a szerzö kísérletet tesz a nonprofit szervezetek e területen való részvételének és szerepeinek feltárására - a LEADER+ Program szemüvegén keresztül. Az elemzés vizsgálati területeként Magyarország hét fejlesztési régiója közül a Dél-Dunántúli Régió került kiválasztásra. A vizsgálati eredmények, és az áttekintett szakirodalom alapján a szerző arra a következtetésre jut, hogy a vidéki nonprofit szervezeteknek fontos szerepe van a vidéki lakosság aktivizálásában és mozgósításában.

Kulcsszavak: vidékfejlesztés, nonprofit szervezetek, LEADER Program, Dél-Dunántúli Régió

\section{Introduction}

Rural development is a well-known expression all over the world, both in developed and developing countries. But while its importance is acknowledged almost everywhere, its content may vary from region to region, as rural problems such as changing roles of agriculture, aging or depopulation manifest in different ways. But one common feature can be identified at most places, the moving emphasis from top-down to bottom-up rural development, as a result of a paradigm shift from the 1970's. The latter paradigm brought localities, local communities and organisations into focus. Their participation, roles and functions became revaluated in the development process. European development programmes, like the LEADER Programme for

\footnotetext{
${ }^{1}$ The paper was prepared with the financial support of the Foundation for Hungarian Higher Education and Research

2 Varga Ester, PhD. Student, University of Pécs, Szantó Kovács János u. 1/B, H-7633 Pécs, Hungary, e-mail: stvarga@freemail.hu
} 
example, also followed this path and provided support for local actors to help them realize their development plans.

In Hungary, a country of ten million people in Central Europe, the above mentioned paradigm shift could effectively begin only after the regime change, when after forty years the central bureaucratic system gave place to the local development system. This was the time when nonprofit organisations started to come into existence en masse in the whole country, including rural areas.

In this paper my goal is to examine the participation and contribution of non-profit organisations in the Hungarian rural development. I'm looking for the answers for the following questions: How Hungarian non-profit organisations participate in local rural development? And what role do they play? As a study area, a certain region (Southern Transdanubian Region) and a certain programme (LEADER+ Programme) were chosen in Hungary.

\section{Theoretical Background}

\subsection{Rural areas}

If we examine the notion of 'the rural' in the European academic discourses, different approaches can be identified. The European Spatial Planning Observation Network (ESPON) in its 'Urban-rural relations in Europe' thematic project differentiates four principle approaches connected to four phases of discussion (ESPON, 2005, p. 68). In the first phase, rurality was connected to particular spaces and functions. Rural areas were described through non-urban characteristics or through rural identity, such as open spaces, small settlements or certain behavioral qualities. This traditional set of approaches still continues to attract attention.

According to the ESPON research, the second phase of conceptualizations was brought about by the political economy approaches and the notion of rurality was undermined. The causes of changes in rural areas were often considered to originate from national and international economy, on a rather non-spatial basis. The researchers came to question whether the rural places actually represent distinct localities. These approaches continue to influence academic debates especially in connection with the discussions around globalization and global-local relations.

In the third phase, it was claimed that a single rural space cannot be defined. Instead it was suggested that a number of different social spaces overlap the same geographical space. According to this set of approaches, rurality was a social construct. The meanings of rurality and their interconnections with the agencies and structures played out in various spaces are still seen as questions of major interest.

And finally, the fourth phase was connected to deconstructionist approaches and it was claimed that in post-modern times symbols are becoming detached from their referential base. In rural studies, therefore the task was to reflect how the socially constructed rural space becomes detached from the actual geography of every day life in the rural areas. Many scholars devoted themselves to exploring the complexities and ambivalences of the rural.

In this paper, we approach rural areas in the traditional way, and accept the working definition of the LEADER+ Programme for rurality. It covers areas of population density of or under 120 persons $/ \mathrm{km} 2$ or settlements with a population under 10,000 inhabitants. The analysis of rurality indices show that the area determined by the complex rurality index in Hungary is the same as the above mentioned areas (ARDOP, 2006, p. 130).

According to these criteria, rural areas account for $95 \%$ of the settlements, $87 \%$ of the territory, and $45 \%$ of the population in Hungary (NHRDP, 2007, p. 12) where rurality can be equated with backwardness, a relative dominance of agriculture and depopulation over the national average (Csatári et al, 2007, p. 307). Fig. 1. shows the state of development (from dark blue to red according to factor values) of micro regions together with the rurality index (based on population density of the area and indicated with a white circle). As it is illustrated by Fig. 1, there is no very developed (red) and only 8 developed (orange) rural areas in the country. And at the same time, all backward (dark blue) micro regions have a rural character, described with high level of 
unemployment, high rate of workforce in the agrarian sector, low infrastructure density and poor accessibility (Csatári et al, 2007, p. 307).

Within these circumstances, rural development has a crucial part to take.

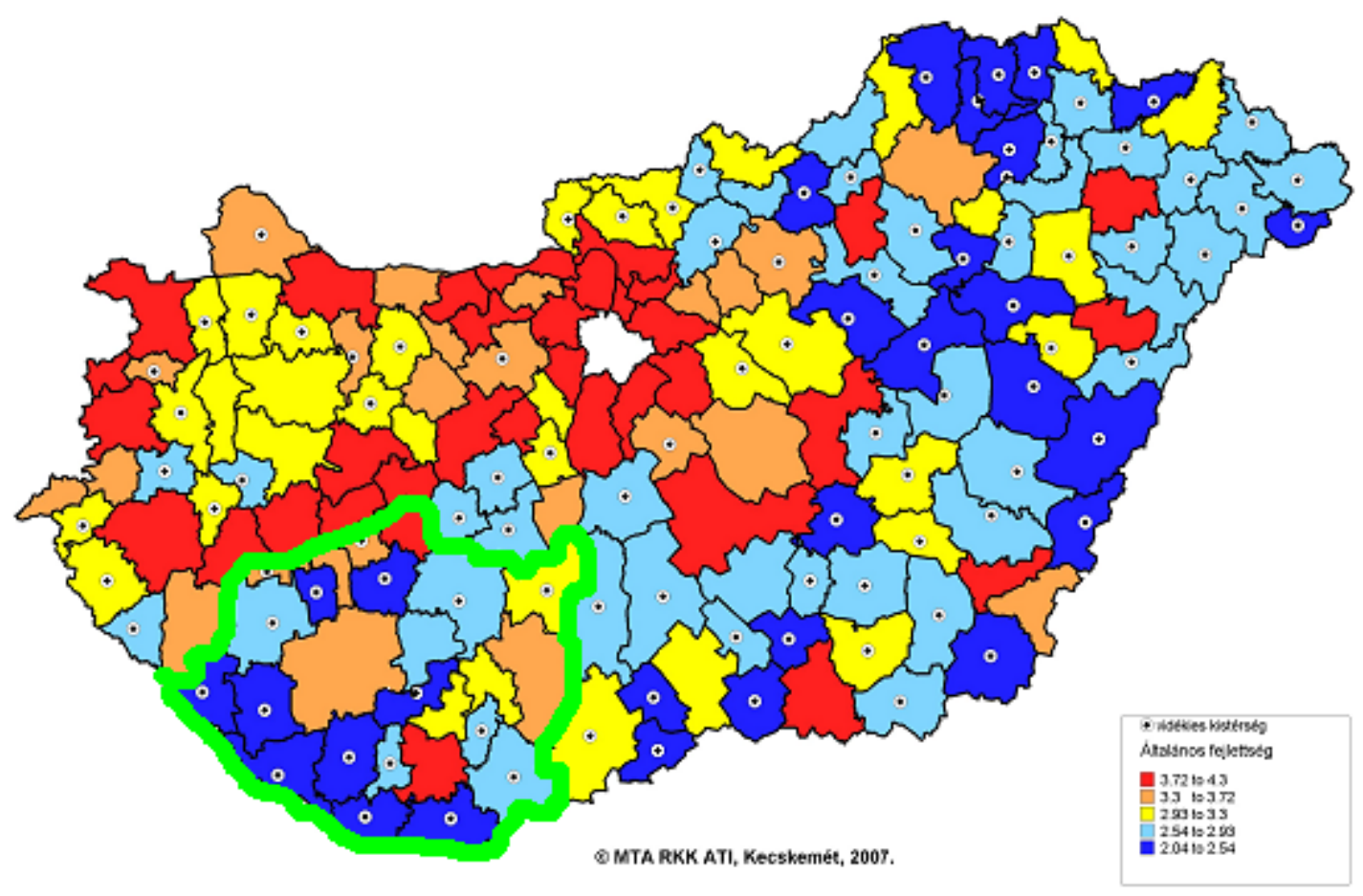

Fig 1. Factor values expressing state of development of Hungarian micro regions (the sign placed in the regions shows rurality index based on concentration of population density)

Source: CSATÁRI, B. et. al. (2007) - supplemented with own modification: the green line encircles the Southern Transdanubian Region examined later in he paper.

\subsection{Rural development}

According to researchers of the International Center for Peace and Development (Jacobs et. al., 1997) human development can be depicted as a process progressing from experience towards comprehension. This development has a subconscious and a conscious part. In this sense, the normal process of development is subconscious that is it is carried out before the conscious understanding has been fully acquired.

Based on the aforementioned approach, we consider (rural) development as a planned changing process based on experiences brought to the level of consciousness. Of course the content of development can vary according to the filter through which conscious understanding proceeds and according to the system of values, interests and power of the individuals or groups who utilize the experiences.

Theories of development have been altering continuously with the changing of viewpoints. We can, for example, examine it from a spatial aspect or dimension. When we connect spatial as an adjective to the notion of development, we indicate only that spatiality is regarded as an emphasized aspect of analysis and not as an element always present in the development process (Nemes Nagy, 1998, p. 171). Rural territories as a special type of space can be examined and developed.

Within the science of rural development, several paradigm shifts have been taken place from time to time. In rural development the latest large shift has been evolved from the 1970's when the top-down development paradigm - grounded in the neoclassical development theories, aiming at rationalization, intensification and economic growth - proved to be unsuccessful in easing regional inequalities (G. Fekete, 2001, p. 12). The new paradigm grounded on a completely new philosophy, focuses on local, bottom-up development. Its main pillars are the 
followings: the center of the development process is man; development must be complex and taking sustainability, public participation and development partnerships into consideration.

The paradigm shift does not mean that only bottom-up approaches have a place in rural development. According to Gusztáv Nemes (Nemes, 2005, p. 2), in the national rural development space two characteristic systems can be clearly identified. The first is the central bureaucratic and the other is the local heuristic system. The central administrative system is based on fundamentally top-down interventions of the political centre. It has a formalized and institutionalized character. It is based on written rules, established procedures and controlled by bureaucratic institutions. It uses external resources for intervention, usually works with a very narrow flow of information, with high transaction costs and aims at quantifiable results. At the same time it can have a large scope and embrace higher level or long term strategic objectives, which are above short term economic rationality. The other type could be called the local heuristic system of rural development, based on essentially endogenous, bottom-up processes. It comprises such elements as: local economic, political and social actors; local development plans; social networks and kinship relations and local authorities. This type of development tries to give flexible responses for internal and external challenges and possibilities in order to protect and improve local life and values, keeping benefits mainly for the locality (Nemes, 2005, pp. 27-28).

These two rural development systems should work in co-operation, complementing each other, forming an integrated development system. In a country where only the central bureaucratic system was allowed to operate for a long time (for about 40 years), the local heuristic system needs special care and attention to be able to get revitalized. Within the framework of a Europewide rural development programme: the LEADER, this became realizable.

\subsection{Non-profit organisations}

When reviewing international literature of non-profit organisations, we can make an interesting observation: research concerning the so called third (or non-profit) sector comprises two distinct groups (Lewis, 1998). Studies of the first group deal with organisations and their activities of developed, industrial countries (we can call this non-profit literature), while investigations of the other group focus on organisations of developing countries (let us call it - referring to their name used there - NGO that is non-governmental literature). Both literatures are interdisciplinary social science fields which intend to combine different aspects of economics, political science, sociology and anthropology and yet they remain different and separate from one another. The NGO literature has been focused on NGO roles in the 'aid industry' and on development practice. By contrast, the non-profit literature has been considering theoretical questions such as the different explanations for the existence of the third sector and policy issues such as the growth of contracting. It has concentrated on service delivery and welfare organisations more than advocacy and social change organisations and has given a higher priority than the NGO literature to organisational structure and management issues (Lewis, 1998, pp. 2-3).

\begin{tabular}{|c|c|c|}
\hline Name & Non-profit literature & Non-governmental (NGO) literature \\
\hline Countries in focus & Developed countries (the North) & Developing or aid-recipient countries (the South) \\
\hline Field of research & Interdisciplinary social science & Interdisciplinary social science \\
\hline \multirow[t]{2}{*}{ Research focus } & 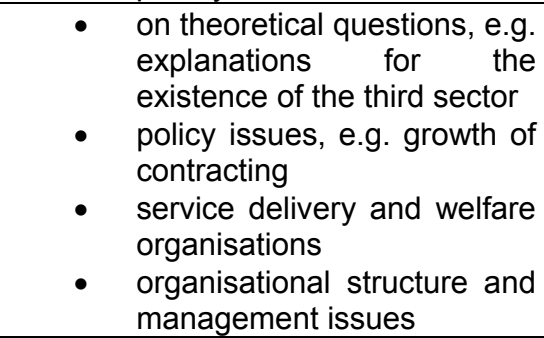 & $\begin{array}{l}\text { - } \quad \text { on NGO roles in the 'aid industry' and } \\
\text { on development practice } \\
\text { - advocacy and social change } \\
\text { organisations } \\
\text { - organisational issues have been rare }\end{array}$ \\
\hline & $\begin{array}{l}\text { Focuses on the organisations } \\
\text { themselves and on the concept of the } \\
\text { 'sector' as a distinctive subject of } \\
\text { research }\end{array}$ & $\begin{array}{l}\text { See NGOs as one of a number of key actors in } \\
\text { processes of development alongside the state, } \\
\text { local government, foreign donors and private } \\
\text { corporations }\end{array}$ \\
\hline
\end{tabular}

Tab 1. Comparison of the two distinct groups of the third sector research

Source: own construction based on LEWIS, D. (1998). 
As far as the Hungarian literature and common talk are concerned, it has to be mentioned that the terms of 'non-profit organisation', 'civil organisation', 'non-governmental organisation' or 'voluntary organisation' are usually used in a more or less synonymous meaning. But while 'non-profit' rather refers to the separateness of these groups from the profit-oriented business world, 'civil' indicates their bottom-up character and their independence from the state. After conducting a quick research on the Internet ${ }^{3}$, we can say, that in Hungarian 'civil organisation' is the most frequently used expression among the four mentioned terms on the Internet (Google, 2008).

In this paper the term 'non-profit organisations' was chosen due to different reasons. One of them is the phenomenon that in the Hungarian LEADER+ the independence of these organisations from the profit-oriented sector is much more inevitable than their separateness from the (local) government sector. Another reason is that one of the most relevant sources of information about these organisations, the Hungarian Central Statistical Office, uses this term in its statements.

According to the definition of the applied notion, associations (egyesület), private and public foundations (magán- és közalapítvány) and public benefit companies (közhasznú társaság) are considered as 'non-profit organisations'.

In the LEADER+ Programme non-profit organisations occupy a very important position, since without their certain level of participation a Local Action Group (LAG) could not be supported. The Programme requires that "Local action groups must consist of a balanced and representative selection of partners drawn from the different socioeconomic sectors in the territory concerned. At the decision-making level the economic and social partners and associations must make up at least $50 \%$ of the local partnership" (Commission Notice, 2000, point 12).

Furthermore, non-profit organisations can also be leaders or gestors of the LAGs. The previous means that they can be the one who hands in the application for support on behalf of the LAG, while in the latter case, they can be elected to make their administrative capacity available for the LAG.

\section{Methodological Background}

In the subsequent part of the paper, non-profit organisations of the Southern Transdanubian Region are studied, especially those taking part in the LEADER+ Programme. First a database of participating organisations was created. A published list of all organisations and projects by region and measures supported through the Agriculture and Rural Development Operational Programme was used as a starting point (Published list, 2008) ${ }^{4}$.

When project content was not clear from the project name in the above list, extra information could be retrieved from the action plans of the LAGs. Usually these were accessible from the web page of the Hungarian Leader Observatory (Leader Observatory, 2007).

Another information source was the newly introduced search engine on the home page of the National Council of Justice of Hungary (Search Engine, 2008), which made it possible to search entries of societal organisations and foundations in the register.

As far as public benefit companies are concerned, another search option (CompLex Search, 2008) had to be used, since the previous one does not contain their list. In both cases organisations had to be checked one by one which made the processing work very time consuming.

After grouping the results according to organisational types, project locations and other relevant variables, the analysis could be executed.

\footnotetext{
${ }^{3}$ Typing the Hungarian equivalent of 'civil organisation', the Google Search Engine offers approximately 257,000 hits, while this figure is 90,700 for 'non-profit organisations, 10,360 for 'non-governmental organisations, and 1,430 for 'voluntary organisations'.

4 During the review period of the paper the Hungarian National Development Agency launched a new interactive website ( http://bir.nfu.hu/emir/oi/stat/ ) where continuously refreshed data is available in a more structured and userfriendly form.
} 
For typifying project activities Lukesch's method was used (Lukesch, 2007, pp. 20-22). When talking about local partnerships he differentiates three types of innovative actions. The type of action around which the project is built up, determines the type of project itself.

The first one is called 'animation action'. These move people and bring them together in new ways, allow changing the look on local aspects, turning barriers into potentials. Actions of this type aim to create meeting spaces and fora, to prise open incrusted structures and beliefs. They stir up innovative ideas and encourage people to live their dreams. Animation actions aim at discovery.

The second type is called 'structuring action'. This modifies the area's tangible or intangible environment to make it more conducive to the sustained creation of activities. This can consist in "hard" infrastructure and business investments, the birth of a new partnership or organisation, or the creation of a new brand.

And the third one is the 'consolidating action'. This aims to ensure viability and overall sustainability of socioeconomic activities. They enhance territorial competitiveness by considering all aspects which contribute to it in the long term. Consolidation means to embed innovation into the socio-economic context of the area. Actions of this type frequently relate to building up local clusters and integrated value-added chains, territorial marketing concepts etc.

Although Lukesch introduced a questionnaire in order to make the process easier, the possibility of subjectivity could not be completely excluded during project identification.

By typifying the projects, some conclusions can be made along Lukesch's model (Lukesch, 2007, p. 23) illustrated in Fig. 7. Regarding Local Action Groups, the model describes eight modes of governance (existence, identity, power, legitimacy, achievement, equality, uniqueness, and sustainability) and three modes of operation which can be exemplified for instance with concrete activities or projects (animating, structuring, and consolidating). There is usually a mix of activities and projects, but it is possible to locate the LAG somewhere in the grid made up of the above mentioned two dimensions. As the diagram below shows, there is a connection between the modes of operation and the modes of governance.

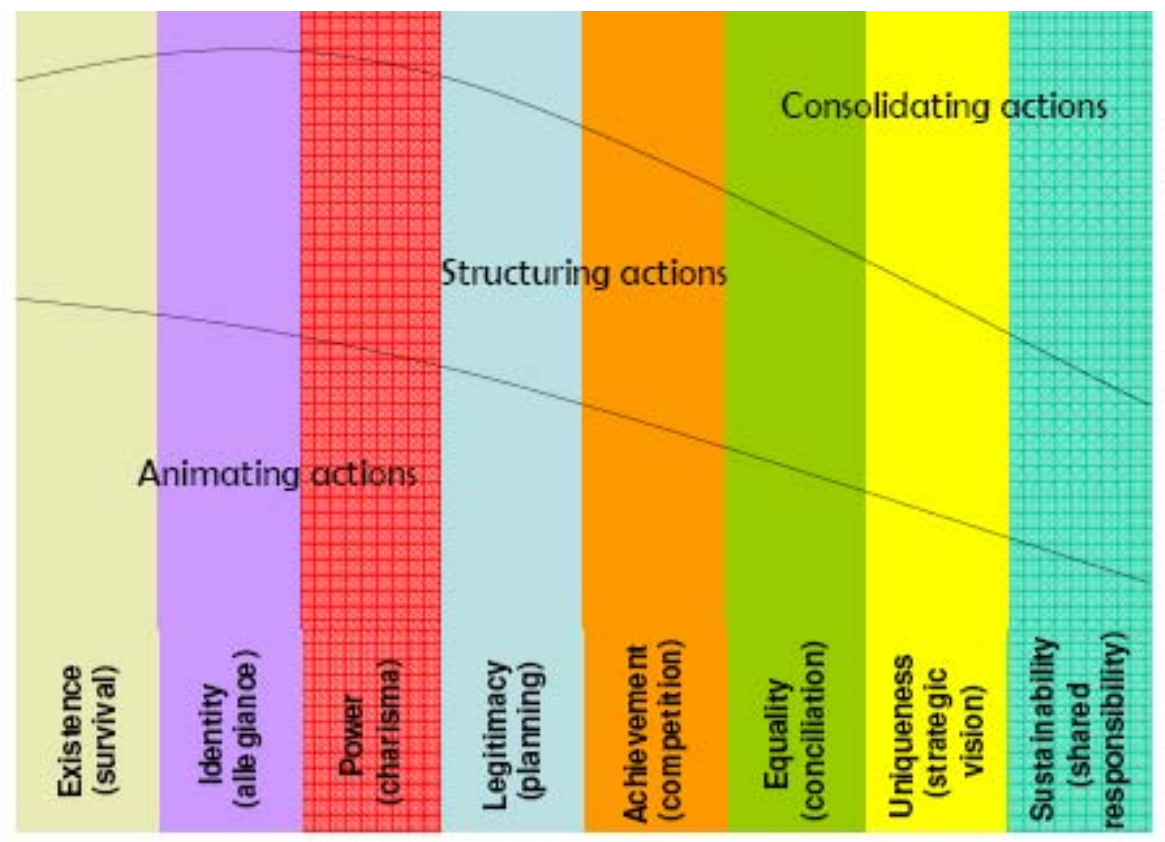

Rising complexity

Fig 7. Lukesch's model

Source: Lukesch, R. (2007).

According to Lukesch, in less diversified, less evolved socio-economic contexts (left side), the need for animating actions will be more significant than in others, whereas consolidating actions will be dominant in more prosperous and diversified rural areas (towards the right side). 
In Lukesch's theory, if a LAG has successfully accomplished an innovation cycle which ended up in a consolidating phase, it may restructure itself and starts to work on new themes in an animating style.

\section{Empirical Knowledge}

\subsection{The LEADER+ Programme}

During the previous European programming period, the so called LEADER+ Programme was implemented through the Agriculture and Rural Development Operational Programme in Hungary which was one of the five Operational Programmes of the National Development Plan. Within the LEADER+ framework, 70 Local Action Groups were selected for support to carry out integrated small regional pilot programmes at the local level. These aimed at diversifying the agricultural activities and expanding the rural business activities, such as developing rural tourism (the latter includes on-farm tourism) and handicrafts and the marketing of quality products. Support was also provided to improve the quality and the conditions of life of rural population by the development of adequate rural infrastructure and the establishment of a more attractive residential environment, by strengthening rural communities and preserving and improving the natural and cultural heritage (ARDOP, 2006, p. 6).

According to the LEADER approach, LAGs are partnerships of local municipalities, entrepreneurs and non-profit organisations. With the involvement of the above mentioned 70 LAGs, 2680 projects were selected for support in the last programming period. This accounts for approximately $13 \%$ of all supported projects of the National Development Plan, while in financial terms this means less than $1 \%$ of the total sum of awarded support. One LEADER+ project received nearly $€ 10,000$ on an average ${ }^{5}$. This average amount was around $€ 145,000^{6}$ considering all projects of all Operational Programmes in the country (National Development Agency [NFÜ], 2008).

\subsection{The Southern Transdanubian Region}

When talking about spatial and rural development, Hungary can be divided into seven development regions (NUTS 2), as it is listed in Fig. 2. It also illustrates the number of non-profit organisations participating in project implementation within the LEADER+ framework. Out of the previously mentioned 2680 project supports, 669 , that is $25 \%$ were awarded to non-profit organisations (NFÜ, 2008).

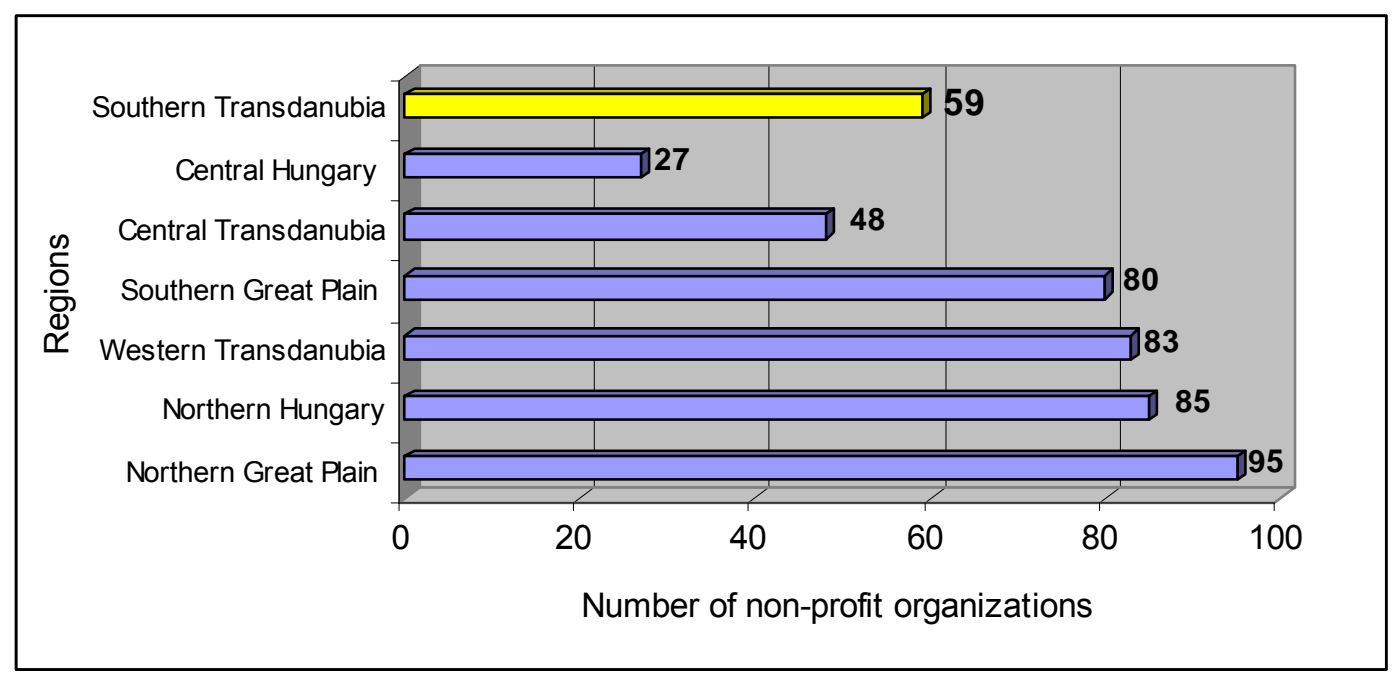

Fig 2. Number of non-profit organisations with supported projects in the LEADER+ Programme in different regions Source: own calculations based on Published List (2008).

\footnotetext{
${ }^{5}$ Based on a 250 HUF/EUR exchange rate

${ }^{6}$ Based on a 250 HUF/EUR exchange rate
} 
In this paper the so called Southern Transdanubian Region (area encircled with green in Fig. 1. and described with a yellow column in Fig. 2.), has been chosen for study area. If reasons for this selection must be named, then apart from the author's personal connection to the area, the typical rural character (as it is depicted in Fig. 1) could be mentioned.

Fig. 3. shows the Southern Transdanubian Region with the indicated areas of the supported Local Action Groups. Within the LEADER+ Programme, ten LAGs were selected from the Region for assistance.

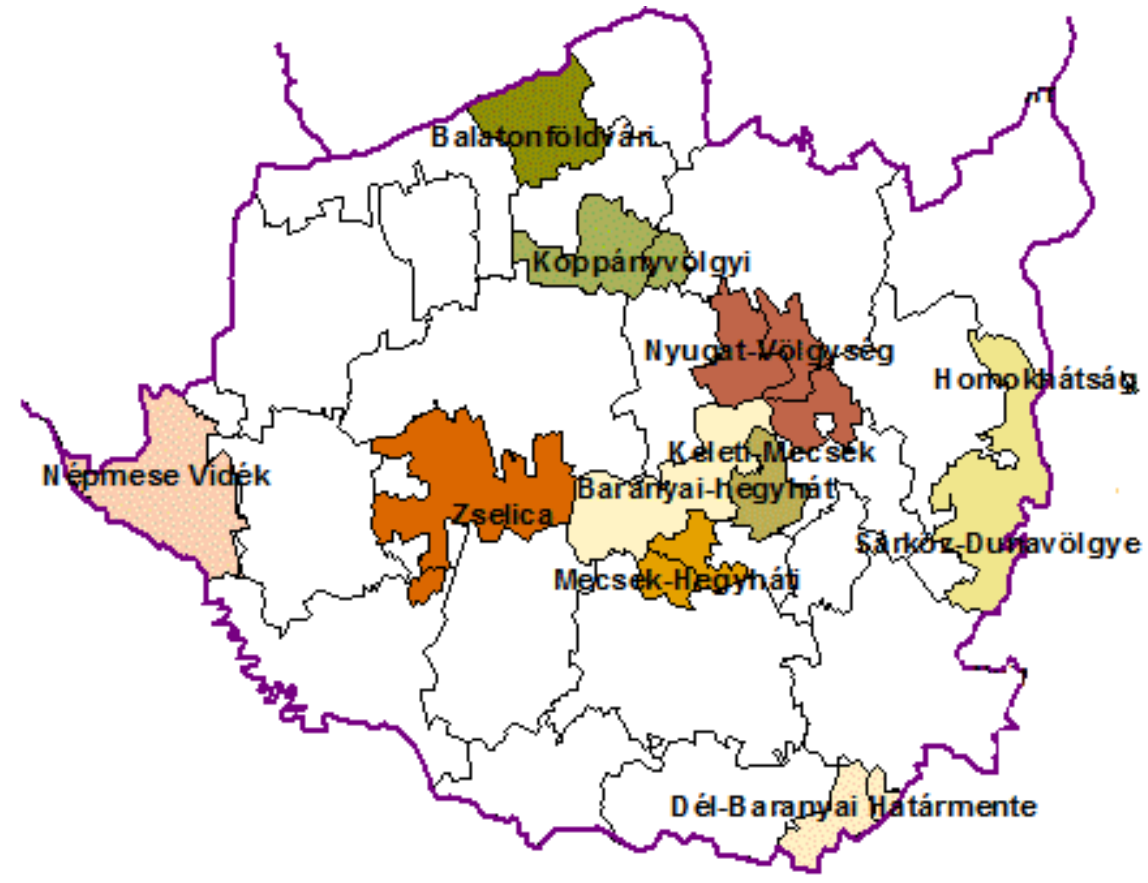

Fig 3. Leader+ Local Action Groups in the Southern Transdanubian Region

Source: Based on Nyertes LEADER+ akciócsoportok (2006) made by VÁTI Kht.

\subsection{Non-profit share comparing to other organisational types}

In the Southern Transdanubian Region, project implementations were dominated by municipal presence. $37 \%$ of the supported entities were municipalities or connected institutions, accounting for $43 \%$ of the supported projects. In the case of non-profit organisations, these rates were $24 \%$ and $25 \%$ respectively. So as in the national level, non-profits represent around one quarter of both organisations and supported projects. But if we add individuals and churches to non-profit organisations, and calling them "civils", this ratio increases up to $51 \%$ and $46 \%$ respectively.

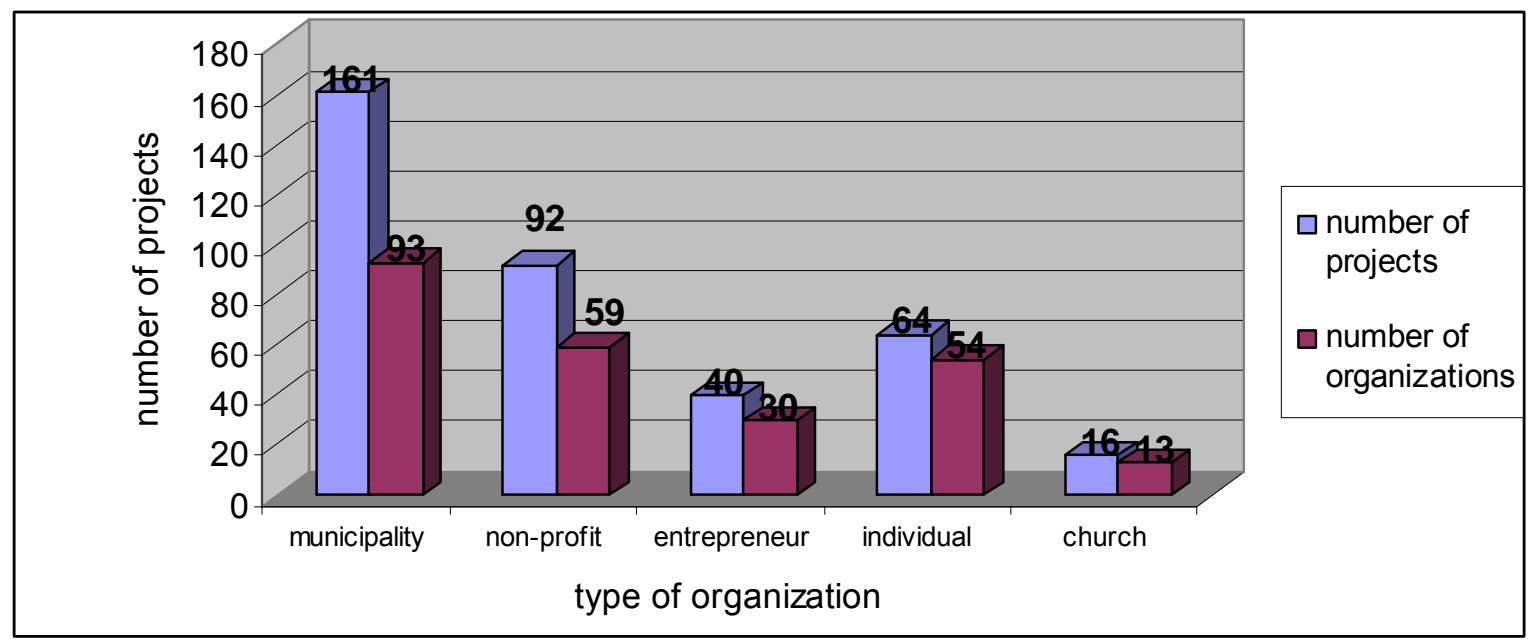

Fig 4. Number of projects and implementing entities according to organisational types in the Southern Transdanubian Region

Source: own calculations based on Published List (2008). 


\subsection{Non-profit participation in the LAG areas}

To be able to determine the real participation rate of non-profit organisations in the LEADER+ Programme, instead of taking all regional nonprofits as a base, only nonprofits operating in a LAG area must be considered. After defining this base and comparing it to the participating non-profit organisations, the following turned out: around $7 \%$ of non-profit organisations existing in the territories of LAGs in the Region participated in the LEADER+ Programme with projects. And on an average each participating non-profit organisation implemented 1.5 projects. It means that usually there is a group of active nonprofits in the LAG areas whose members have sometimes two or more supported projects, while the rest of the non-profit organisations (93\%) have no direct access to LEADER+ funds. Obviously it does not mean that they can not benefit from other's projects but it inevitably illustrates their lack of participation. As an explanation different reasons could be mentioned from the lack of information, time or motivation to the lack of sufficient financial or human resources. Further research could explore the most relevant causes.

\subsection{Leaders and Gestors}

As far as leading organisations are concerned in the case of the 10 selected LAGs in the Region, it can be said that they are generally municipalities (excepting one that is public foundation). The reason for this might be that since leaders have a representing role to play -as they are agents of their LAGs -, organisations with a more powerful image are chosen for these positions. And municipalities seem to fulfil this requirement the best.

In the case of gestor organisations when administrative capacity is the most required feature, a more mixed picture can be observed. Only 4 municipalities (out of which one is their association) were chosen for this position. The majority (60\%) of gestors belongs to the group of non-profit organisations in the Region.

\subsection{Decision-making body}

Representation of non-profit organisation in the decision-making body of the Local Action Groups varies from LAG to LAG. In the case of the Southern Transdanubian Region it ranges between $13 \%$ and $37 \%$. In the former case, entrepreneurs and individuals must fill the gap, and complement their number up to $50 \%$.

\subsection{Types of projects}

Analyzing and grouping the projects according to their content is an interesting, hence again a time consuming process. The three main project types were defined by using Lukesch's suggestions. For example organising a village festival; music, dance or local gastronomy programmes were considered animation projects, while building a playground, a club house, renovating a tourist attraction or issuing a tourist guide were taken as structuring ones. The construction of an online hotel reservation system in the area was identified as a consolidating project.

As Fig. 5 illustrates, projects with structuring actions are the most frequent types in the Southern Transdanubian Region, regardless of organisational type. It is followed by animation projects and there is only few consolidating type of projects in the Region.

Compared to other organisations, non-profits implemented the most animation projects. This is the case both in absolute and in relative sense. The former can be easily captured in Fig. 5 while the latter is depicted by Fig. 6 , where it becomes visible that $26 \%$ of non-profit projects are animation types. 


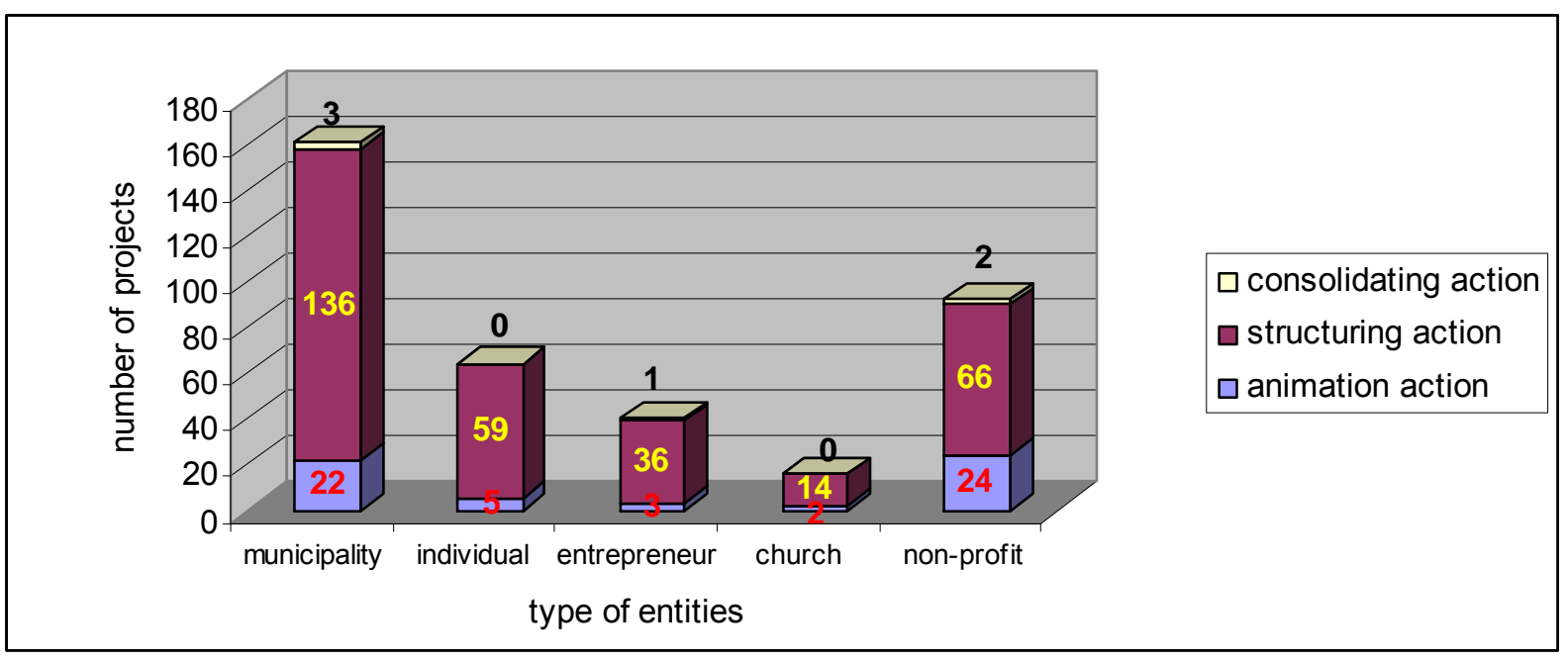

Fig 5. Number of projects according to types of organisations and types of actions in the Southern Transdanubian Region

Source: own calculations based on Published List (2008).

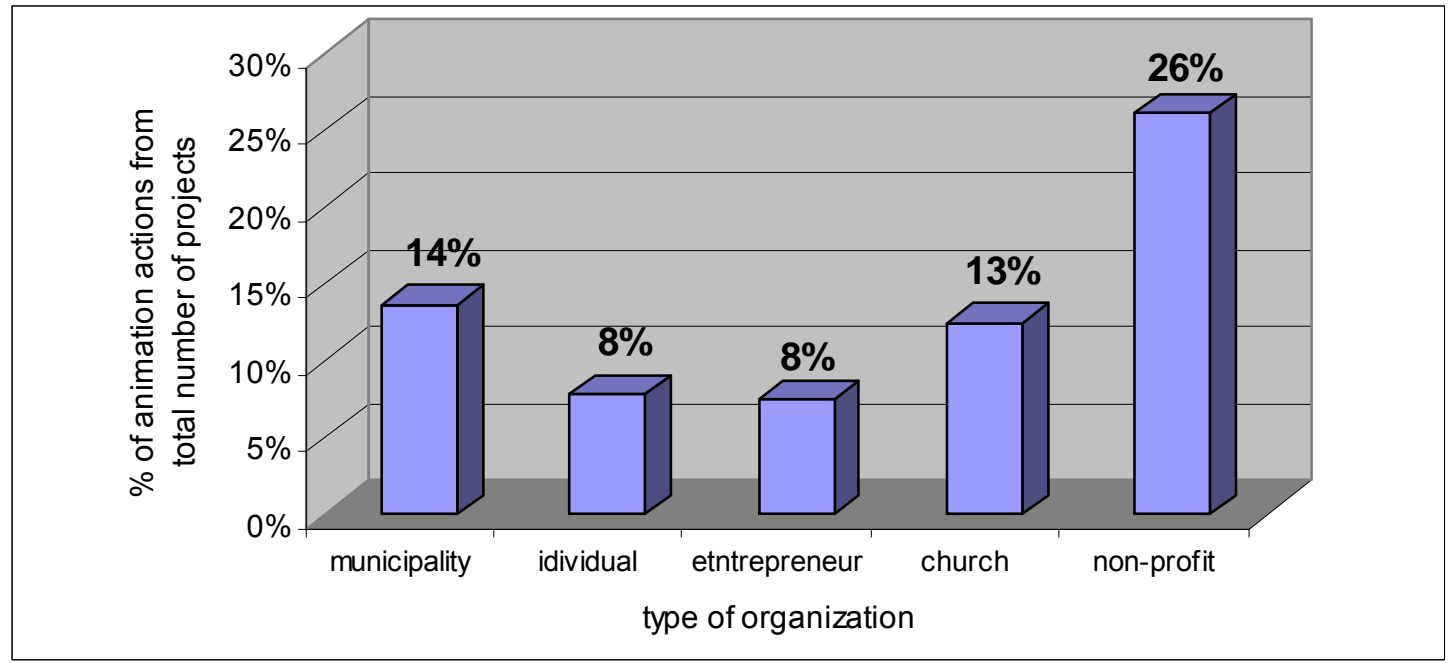

Fig 6. Relative share of animating type projects according to types of organisations in the Southern Transdanubian Region

Source: own calculations based on Published List (2008).

\section{Conclusions}

If Lukesch's model is accepted, and Local Action Groups of the Southern Transdanubian Region should be positioned somewhere, the following notes can be made. Since the level of complexity of the LAGs' socio-economic environment in the studied Region can not be said very high, and taking into consideration the type of projects prevailing, the LAGs in question might be positioned somewhere in the middle of Lukesch's model. So space for evolution that is climbing the eight-step ladder still exists.

Other empirical research justifies (e.g. Mascherini et al, 2007, p. 39) that non-profit organisations can be essential players in civil participation, both as suppliers of information and as platforms for social interactions, that is as animating agents. In the analysis part of this paper there were results referring to this role, showing that non-profit organisations accounted for the highest share in implementing animation projects.

In the future however, this ratio should be still increased, since a significant proportion of the rural non-profit organisations and rural population still needs to be mobilized. 
[1] ARDOP (2006): Agriculture and Rural Development Operational Programme, 2004-2006. Budapest: Ministry of Agriculture and Rural Development. Retrieved September 25, 2007 from http://www.fvm.hu/doc/upload/200606/avop_eng_060627.pdf

[2] Commission Notice (2000): Commission Notice to the Member States. Laying down guidelines for the Community initiative for rural development (Leader+). (2000/C 139/05). Retrieved April 23, 2008. http://eurlex.europa.eu/LexUriServ/LexUriServ.do?uri=OJ:C:2000:139:0005:0013:EN:PDF

[3] CompLex Search (2008): webpage of the CompLex Business Search. Retrieved June 1, 2008. http://www.ceghirek.hu/nevado.php

[4] CSATÁRI, B. et al. (2007): „A környezet és a kultúra szerepe a vidéki változásokban,” In: Stratégiai kutatások 2006-2007: Kutatási jelentések [Research Report]. MTA-MEH Budapest. Retrieved May 22, 2008. http://www.mta.hu/fileadmin/2007/11/MeHMTA\%20IV_302-326.pdf

[5] ESPON (2005): Urban-rural relations in Europe [Research Report]. Centre for Urban and Regional Studies Helsinki University of Technology. http://www.espon.eu/mmp/online/website/content/projects/259/649/index_EN.html

[6] FOWLER, A. (2000). Civil society, NGDOs and social development: changing the rules of the game. Occasional Paper No.1. United Nations Research Institute for Social Development Geneva. Retrieved December 12, 2005.

http://www.unrisd.org/unrisd/website/document.nsf/0/f553495f06f98dce80256b5e005c9ddc/ \$FILE/fowler.pdf

[7] G. FEKETE, É. (2001). "Együtt! - De hogyan?" Innovációk a kistérségi fejlesztésekben. MTA Regionális Kutatások Központja Miskolc-Pécs.

[8] Google (2008): Google Search Engine. Retrieved September, 18, 2008.

http://www.google.hu/

[9] JACOBS, G. et. al. (1997): Comprehensive theory of social development. Retrieved September 10, 2007.

http://www.icpd.org/development_theory/comprehensive_theory_of_social_development.htm

[10] Leader Observatory (2007): web page of the Leader Központ. Retrieved May 12, 2008. http://www.leaderkozpont.hu

[11] LEWIS, D. (1998): Bridging the gap?: The parallel universes of the non-profit and nongovernmental organisation research traditions and the changing context of voluntary action. London Centre for Voluntary Organisation, London School of Economics London. Retrieved January 23, 2007. http://www.Ise.ac.uk/collections/CCS/pdf/IWP/int-work-paper1.pdf

[12] LUKESCH, R. (2007): The LAG-handbook: A guide through the stunning world of local action groups. Retrieved October 26, 2007.

http://ec.europa.eu/agriculture/rur/leaderplus/pdf/library/methodology/lukesch_handbook.pdf

[13] MASCHERINI, M. et. al. (2007): Participation in Europe: one-size-fits-none. Institute for the Protection and Security of the Citizen (European Commission, Directorate-General Joint Research Centre, Institute for the Protection and Security of the Citizen) Luxembourg. Retrieved September 3, 2007. http://crell.jrc.ec.europa.eu/participation/participation.pdf

[14] NEMES, G. (2005): Integrated rural development: The concept and its operation. Magyar Tudományos Akadémia Közgazdaságtudományi Intézet Budapest. Retrieved August 20, 2007. http://econ.core.hu/doc/dp/dp/mtdp0506.pdf

[15] NEMES N. J. (1998): A tér a társadalomkutatásban. Bevezetés a Regionális tudományba. Hilscher Rezső Szociálpolitikai Egyesület „Ember-Település-Régió” Budapest. Retrieved October 4, 2007. 
http://geogr.elte.hu/REF/REF_Kiadvanyok/Ter_a_tarskutban/A_Ter_a_tarsadalomkutatasba n_NNJ.htm

[16] National Development Agency (NFÜ). Retrieved September 18, 2008.

http://213.16.82.69/emir.nfu.hu/nd/kozvel/\#

[17] NHRDP. (2007): „New Hungary” Rural Development Programme, 2007-2013. Budapest. Retrieved September 25, 2007.

http://www.fvm.hu/doc/upload/200709/new_hungary_rural_development_programme_official _20092007.pdf

[18] Nyertes LEADER+ akciócsoportok (2006). Váti Kht. Retrieved September 7, 2007. http://ec.europa.eu/agriculture/rur/leaderplus/memberstates/enlarge_hu.htm

[19] Published list (2008): Az Agrár- és Vidékfejlesztési Operatív Program nyertes pályázóinak listája az Egységes Monitoring és Információs Rendszer alapján, 2008. január 10-i állapot szerint. Retrieved May 12, 2008.

http://www.fvm.hu/doc/upload/200801/avop_ddtul_080110.pdf

[20] Search Engine (2008): webpage of the Registry Court. Retrieved May 20, 2008. http://www.birosag.hu/engine.aspx?page=tarsszervsearch 